\title{
The skull on the hill. Anthropological and osteological investigation of contemporary horse skull ritual practices in central Mongolia (Arkhangai province)
}

\author{
Charlotte MARCHINA \\ EA 4512 ASIEs, \\ Inalco, Université Sorbonne Paris Cité, \\ 2 rue de Lille, F-75007 Paris (France) \\ charlotte.marchina@inalco.fr
}

Sébastien LEPETZ

UMR 7209 Archéozoologie, Archéobotanique, Sociétés, Pratiques et Environnements, CNRS, Muséum national d'Histoire naturelle, Sorbonne Universités, case postale 56, 57 rue Cuvier, F-75231 Paris cedex 05 (France) and Mission archéologique française en Mongolie lepetz@mnhn.fr

Claude SALICIS

Institut de Préhistoire et d'Archéologie Alpes Méditerranée, 29 corniche Frère Marc, F-06000 Nice (France) claude.salicis@free.fr

Jérôme MAGAIL

Musée d'Anthropologie préhistorique de Monaco, 56 bis boulevard du Jardin Exotique, MC-98000 Monaco (Principauté de Monaco) and Mission archéologique conjointe Monaco-Mongolie jerome.magail@map-mc.com

Published on 29 December 2017

Marchina C., Lepetz S., Salicis C. \& Magail J. 2017. - The skull on the hill. Anthropological and osteological investigation of contemporary horse skull ritual practices in central Mongolia (Arkhangai province). Anthropozoologica 52 (2): 171-183. https://doi.org/10.5252/az2017n2a3

\section{ABSTRACT}

Among the five kinds of animals Mongolian herders breed (i.e. horses Equus caballus Linnaeus, 1758, camels Camelus bactrianus Linnaeus, 1758, cattle Bos taurus Linnaeus, 1758, Bos grunniens Linnaeus, 1766, and their hybrids, sheep Ovis aries Linnaeus, 1758, and goats Capra hircus Linnaeus, 1758), the horse holds a particular status, perceivable in the slaughtering techniques used and the way its skull is treated after death. Leaving horse skulls in high places (i.e. trees, mountains, and ovoos - stone cairns erected in homage to the master spirits of a place) is a common, though poorly understood, practice. This article studies the modalities of these horse skull repositories within an interdisciplinary approach, combining social anthropology and osteology. The study of the choice of place for the skulls and their associated objects highlights the

KEY WORDS Mongolia, horse, husbandry, slaughtering, ritual, cairn, osteology. differentiation processes among the horses as individuals, in relation to their lifetime status. This relation between human and horses unfolds into the landscape, which is invested with numerous ovoo cairns and horse skulls; a reminder that these spaces are shared between humans, horses and invisible entities. In the absence of private land ownership on the Mongolian steppe and in the interest of a balanced coexistence with all the inhabitants of this shared land, we show that the horse skull repositories subtly combine honour to individual horses, respect to the master spirits of the land, and discrete appropriation of territory by herders. 


\begin{abstract}
RÉSUMÉ
Le crâne sur la colline: enquête anthropologique et ostéologique sur les pratiques actuelles de dépôts de crânes de chevaux en Mongolie centrale (province d'Arkhangai).

Parmi les cinq types d'animaux que les éleveurs mongols élèvent (chevaux Equus caballus Linnaeus, 1758, chameaux Camelus bactrianus Linnaeus, 1758, bovins Bos taurus Linnaeus, 1758, Bos grunniens Linnaeus, 1766 et leurs hybrides, moutons Ovis aries Linnaeus, 1758 et chèvres Capra hircus Linnaeus, 1758), le cheval bénéficie d'un statut particulier, notamment perceptible dans les techniques d'abattage et le traitement de son crâne après sa mort. Les dépôts de crânes de chevaux sur des lieux élevés (arbres, montagnes et cairns ovoo érigés en hommage aux esprits maîtres des lieux), sont courants, mais pourtant encore mal connus dans leurs modalités pratiques. Cet article étudie les dépôts de ces crânes dans une approche interdisciplinaire alliant anthropologie sociale et ostéologie. L'étude des choix du lieu de dépôt et des objets accompagnant le crâne lors du dépôt met en évidence des processus de différenciation entre les chevaux, en lien avec le statut qu'ils occupaient de leur vivant.

MOTS CLÉS

Mongolie,

cheval,

élevage,

abattage,

rituel,

rituel,
cairn,

ostéologie.

Cette relation entre humains et chevaux se déploie dans le paysage, qui est investi de nombreux cairns ovoo et de crânes de chevaux, rappelant que ces espaces sont partagés entre humains, chevaux et entités invisibles. En l'absence de propriété privée sur la terre dans les steppes mongoles, nous montrons que les dépôts de crânes allient subtilement, dans un souci de bonne cohabitation avec tous les occupants de ce pays partagé, hommage à des individus chevaux, respect des esprits maîtres des lieux et appropriation discrète d'un territoire de la part des éleveurs.
\end{abstract}

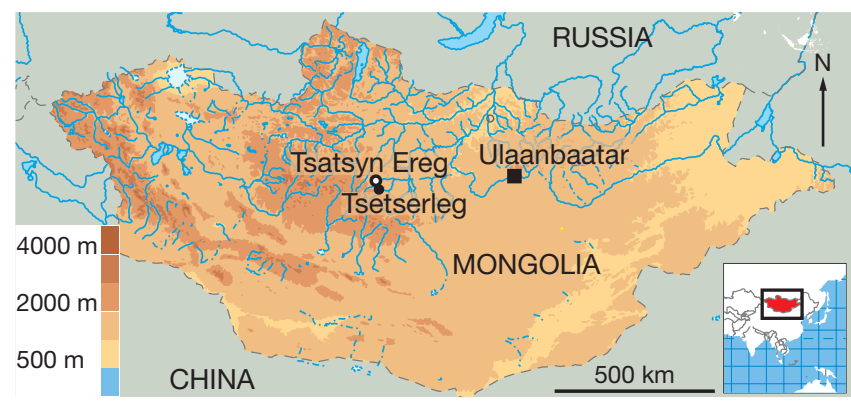

FIG. 1. - Location map of the site of Tsatsyn Ereg.

\section{INTRODUCTION}

Leaving horse (Equus caballus Linnaeus, 1758) skulls in high places is a commonly known practice in Inner Asia, from Kyrgyzstan to Yakutia (Popov 1949: 293; Ferret 2009: 145, 146; 2014). In Mongolia, the heart of "horse civilization" (Ferret 2009), the ethnographic literature mentions that the skulls of "beloved" (Tatár 1976: 18; Atwood 2004: 414) male horses (Birtalan 2003: 56), stallions, good race horses (Fijn 2011: 229), and consecrated horses (Tatár 1971: 305) are left on stone cairns $\left(o v o o^{1}\right)$, mountains, hills, or in trees (Djakonova 1977: 99). However, the actual practice or its modalities have not been thoroughly studied. To our knowledge, only Allard et al. (2007) have specifically addressed horse skull deposits in a preliminary study on contemporary horse meat consumption, treatment of bones, and horse skull deposits in the Arkhangai province. Two specific results of Allard et al.'s quantitative survey indicate that this practice is common and not restricted to particular horses (i.e. stallions, race horses, and other beloved horses), and that there

1. Mongolian terms appear in italics. are constants in the modalities of the deposits: mountains are preferential places, albeit with variations - they can be used repetitively or only once, and the orientation of the skulls may vary. This study was based on interviews with herders from the Arkhangai province, in order to shed light on the horse skulls deposits relating to the Bronze Age funerary structures of the deer stone-khirigsuur complex (see also Allard \& Erdenebaatar 2005). A khirigsuur is a stone burial mound surrounded by a fenced perimeter, satellite mounds and stone circles. Deposited under these mounds and circles are the remains of horse skulls and calcined caprines/ovines. At a time when these Bronze Age structures are extensively studied, yet still continue to raise many aspects of interrogation (see Fitzhugh 2009; Broderick et al. 2014; Seitsonen et al. 2014; Magail 2015; Baroni et al. 2016; Broderick et al. 2016; Taylor 2017), pluridisciplinary research should be encouraged in order to illuminate the relationships between ancient and contemporary practices. As the horse skull repositories of the deer stone-khirigsuur complexes appear to us as structurally inverted ovoos - skulls were placed in first, and then stones were used to cover them - we decided to study in more detail contemporary horse skull ritual practices. Although this work was carried out in collaboration with, and in the framework of, the joint Monaco-Mongolia archaeological expedition ${ }^{2}$ (see Magail 2008), this paper will focus solely on the ethnographical and osteological aspects of the contemporary horse skull practices.

At the archaeological site of Tsatsyn Ereg, Ikhtamir district, Arkhangai province, in the Bayantsagaan valley (Fig. 1), many horse skulls dot the landscape. Left on relatively high hills, in trees, or on sheepfold roofs, some skulls seem to have been carefully orientated: sometimes isolated, or on the contrary,

2. Under the aegis of the Musée d'Anthropologie préhistorique of Monaco and the Mongolian Academy of Sciences. 


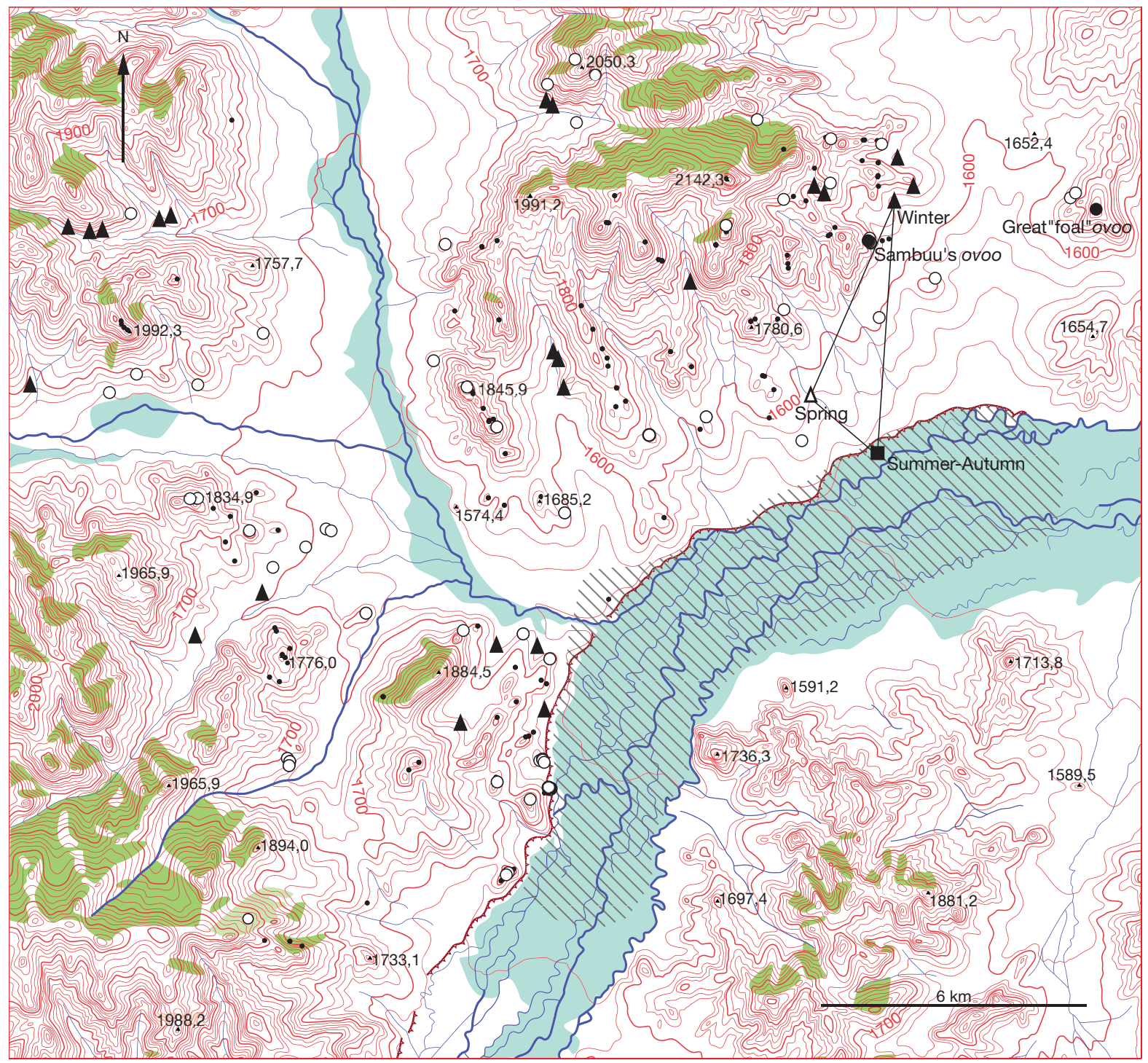

FIG. 2. - • Distribution of the ovoos surveyed north of the Tamir River; $O$, ovoos on which horse skulls were found; $\boldsymbol{\Delta}$, winter encampments of the Bayantsagaan herders. Three linked figures, Sambuu's encampments (winter, spring, and summer). ment. Shaded area, summer encampments of the Bayantsagaan herders (data, C. Marchina, S. Lepetz \& C. Salicis; map, S. Lepetz, based on the background map of the Musée d'Anthropologie préhistorique of Monaco, F. Burle).

grouped together; sometimes with distinctive signs (stones), or even explicitly honorific signs such as a silk scarf (khadag), all of which suggest differences in the treatment of dead horses. The variations in the way the landscape is invested with these horse skulls (i.e. specific places, accompanying objects, and orientation) can only be fully appreciated through full consideration of the relations the herders build with their horses and their territory.

In this study we analysed the horse skull deposits and the discourses that accompanied them by situating them in a triadic relation linking together herders, horses, and the landscape. In order to achieve this, we chose an interdisciplinary approach at the crossroads of anthropology and osteology, using a variety of investigation methods. From 2009 to 2012, we carried out prospections on foot in order to map all the contemporary anthropogenic and archaeological structures of the survey area (Figs 1,2), including the deposited horse skulls (CS), which were carefully observed (SL, CM). In parallel to the field studies and the analysis of osteological items (SL), interviews were conducted (2009, 2011, and 2013) in Mongolian regarding these practices, with eleven herders living in the Bayantsagaan valley and its surroundings (CM \& SL). The locations of the herders' encampments were recorded by GPS (CM). 
TABLE 1. - Distribution of skulls to cairns.

\begin{tabular}{cc}
\hline Number of skulls & Number of cairns \\
\hline 1 & 41 \\
2 & 10 \\
3 & 4 \\
4 & 4 \\
5 & 3 \\
6 & 1 \\
19 & 1 \\
42 & 1 \\
\hline
\end{tabular}

\section{HORSE SKULLS ON HILLS: FUNERARY PRACTICES FOR A RESPECTED ANIMAL}

During our investigation in the surroundings of Bayantsagaan, the herders most frequently mentioned the ovoo as the preferred place to leave horse skulls. An ovoo (literally "pile", in Mongolian) basically consists of a collection of stones. As in other regions of Inner Asia where they are found (referred to as obo, oboo, or ovad) (see Kagarov 1927; Stépanoff 2013: 107), ovoos are located on mountain passes, peaks, hills, or next to water sources inhabited by the master spirits of the land (ezen). When passing these places, Mongolians stop to walk clockwise around them and leave stones or small offerings such as banknotes. More exceptionally, they offer empty bottles of vodka, small prayer wheels, and, sometimes, horse skulls.

We must highlight that hills and mountains with preferential places for leaving skulls are not ubiquitous across Mongolia. In fact, regional and/or ethnic differences may exist in horse ritual practices: while in forested parts of the Northern Khövsgöl province skulls are usually placed in trees (Taylor W. pers. comm.), the Kazakh herders of Bayan-Ölgii province, in the Mongolian Altai, commonly leave the horse skulls in clear places or even rivers, as far as we could observe. It could be that placing horse skulls on ovoos is, in Mongolia, a practice limited to the Khalkh Mongols (Zhambaldorzh 1996: 121, 122), todays' Mongolian ethnic majority.

We identified around 220 of these stone cairns within the prospection zone and observed 171 horse skulls deposited on 65 stone piles. On most of those ovoos there was only one skull; others had several skulls, and one had in excess of 40 (Table 1). Mandibles were generally absent, and only the superior part of the head was left. Consequently, in this paper, we use the term "skull" to refer to the craniofacial complex excluding the mandibula, bearing in mind that in most cases the meat has been removed. When referring to the craniofacial complex including the mandibula we use the term "head". In Mongolian, herders usually use the term "head" (tolgoi) even when referring to the skull.

When we asked the herders for the reasons behind this practice ("Why do you place horse skulls on ovoos?"), we were given two different answers, both of which underlining the particular status of the horse: the horse is considered a "superior" (deed) animal, and is the work companion of the herder (see Marchina 2016). Horses also serve as privileged intermediaries with invisible entities and, although they are no longer sacrificed, some individual horses are, preferentially

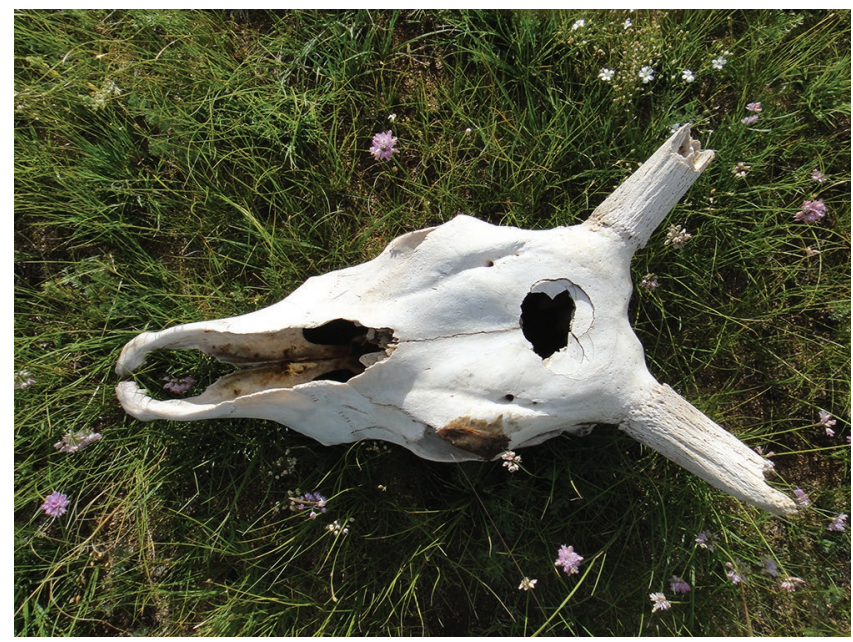

FIG. 3. - Cattle skull with sunken frontal bone, observed on the steppe.

over other species, consecrated to deities, and are allowed to graze freely without being ridden or slaughtered by their herders. As such, the horse is the only animal raised by the Mongols - within the "five muzzles" (i.e. horses, camels Camelus bactrianus Linnaeus, 1758, cattle Bos taurus Linnaeus, 1758, Bos grunniens Linnaeus, 1766, and their hybrids, goats Ovis aries Linnaeus, 1758, and sheep Capra hircus Linnaeus, 1758) - which is provided with a specific post-mortem treatment.

However, the particular status of this species does not save it from being slaughtered. In fact, all interviewed herders stated openly that they eat horse meat. Generally speaking, the herders of each encampment slaughter one horse for the winter. If the slaughtered horse is small or if the herd is large, two horses can be slaughtered; conversely, when the amount of meat is too large for one encampment, the animal can be shared with another family of herders. Horses are generally slaughtered in November. Some herders state that they slaughter them in October and/or December if two horses are to be slaughtered. The extreme temperatures of the Mongolian winter (up to $-40^{\circ} \mathrm{C}$ ) allows for good meat preservation, which is usually stocked in a yurt or a shed without heating, enabling meat to be consumed right throughout the winter until March. When asked why they eat horse meat only during the winter, the herders mentioned concerns about meat preservation, the taste of fresh meat in the summer, and also the energetic characteristics of horse meat specifically: along with the sheep, the horse is an animal "with a hot muzzle" (khaluun khoshuutai), whereas goats, camels, and sometimes cattle, are animals "with a cold muzzle" (khüiten khoshuutai), whose meat is usually not recommended in the winter (see also Ferret 2004). Some herders also stressed a difference in the speed of blood coagulation, higher among the latter than the former.

Horse slaughtering techniques were described by the interviewees and observed in a neighbouring district. The spinal cord is transected with a knife between the skull and the atlas. This action, called nugaslakh, causes the horse to become stunned, and allows the herder to slaughter the animal through external 
bleeding, by cutting the aorta at the base of the neck. This technique is more broadly used with camels, and sometimes cattle. Cattle can also be stunned with the back of an axe (Fig. 3), which precedes, if not replaces, transection of the spinal cord. Slaughtering techniques are radically different for sheep and goats, which are killed by immediate rupturing of the aorta inside the body, causing internal bleeding (see Stépanoff et al. 2013: 198, 199; Marchina 2015: 231-235). During our survey we found three horse skulls from high places which evidenced ante-mortem stunning by hitting on the forehead. The example of one skull displayed in a tree, along with the skulls of another equidae and a calf near the river (Fig. 4) illustrates this practice through the circular impact recorded by the parietal and frontal bones. When asked explicitly if they also stunned horses with an axe, the herders we interviewed unanimously said no. They explained that to break a horse's head in this way would be showing a lack of respect. Mentioning this practice seemed to be embarrassing, as though it was agreed that even if people did it they did not talk about it. It was, however, never denied for cattle.

Mongolian herders consume all the meat of the horse, including the offal with which they make various puddings and sausages. Exceptions were sometimes raised with regards to the legs and to the head, insofar as a horse's head should not be broken: the brain is never eaten, while the other parts of the head often are. We noticed the spontaneity with which the herders mentioned the repository of the head when we specifically asked them whether they eat it ("No", "Yes", and "We place it on a mountain"). According to them, placing the skull on an ovoo usually applies only to horses. Only one herder mentioned that it is possible to leave, along with a horse skull, the skull of a favoured cow that had delivered many calves. Our prospections confirmed that it is mainly equidae which are involved in these acts, although there were three cases where we respectively observed a cattle skull, a sheep skull, and a goat mandible. Aside from the horse's skull, the rest of the bones are rarely kept or used. One herder mentioned the conservation of the scapula and the hyoid bones, which can be hung, along with a tuft of grass, close to the door of the yurt to bring luck and good fortune to the encampment. In two cases we observed hyoid bones on an ovoo. Bone conservation is more frequent for small livestock: the children use ankle bones to play jacks with, and a radio-ulna can be hung on the wall of the yurt to bring strength to the horses (see also Birtalan 2003: 36). However, aside from these bones, the rest are usually thrown away or given to the encampment's dogs.

According to the herders of Bayantsagaan, the horse's skull is always placed on a high place - such as a mountain or an ovoo - irrespective of its sex and status, or whether it was slaughtered or died from natural causes. Indeed, our study showed that horse skulls were more numerous in these high places, although we also found some in trees or on the roof of sheepfolds. No herder readily mentioned the possibility of placing the skull in such places. When asked about this less frequent practice, some herders highlighted that the most important thing was that the repository should be high. Some said they used these locations when hills were too distant, or

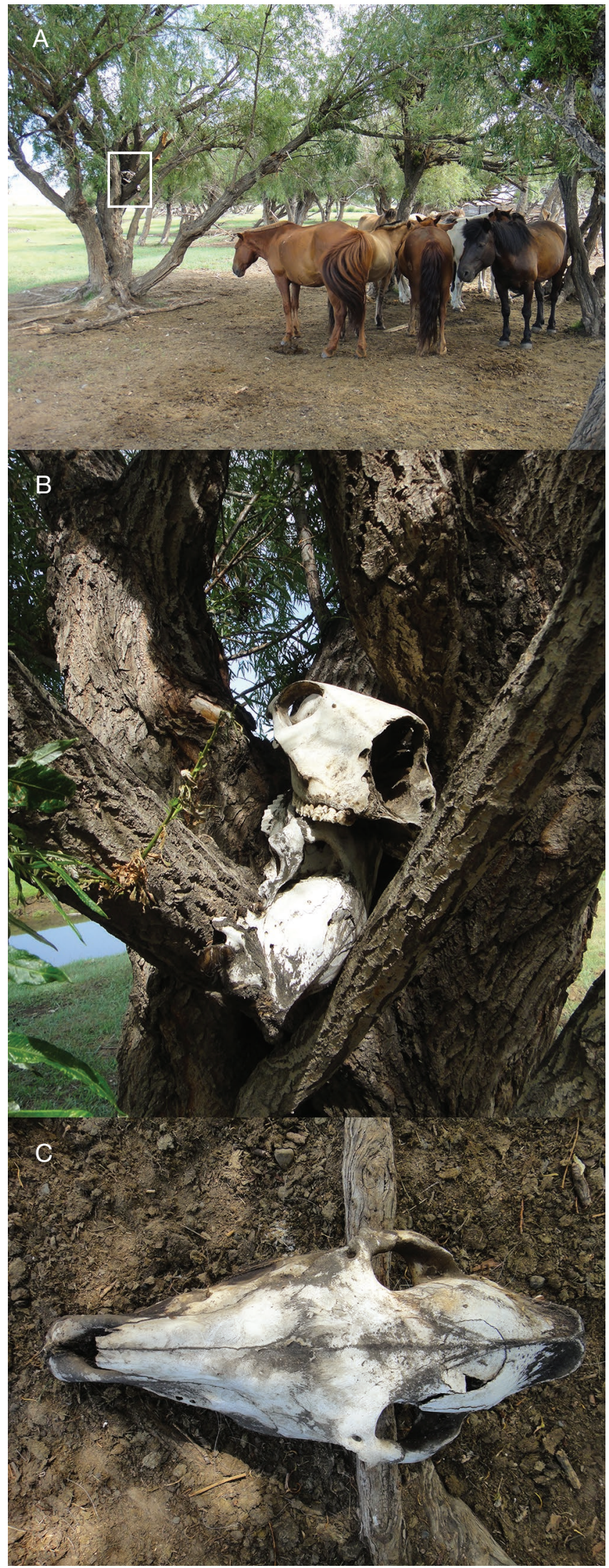

FIG. 4. - A, B, Skulls of three animals (one calf and two horses) placed in a tree; $\mathbf{C}$, one horse skull taken down from the tree for the purposes of the picture, clearly showing a circular mark of ante-mortem stunning on the forehead. 


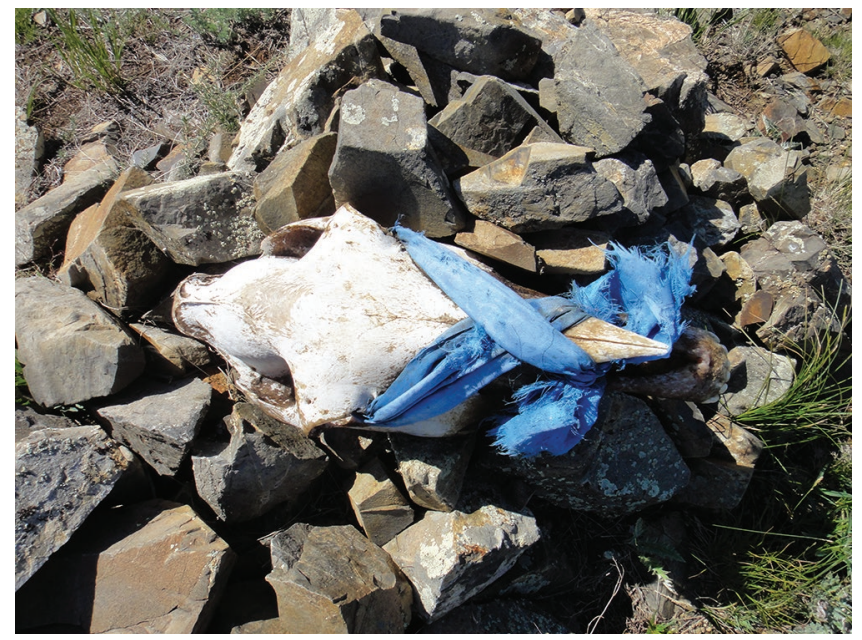

FIG. 5. - Horse skull wrapped in a khadag.

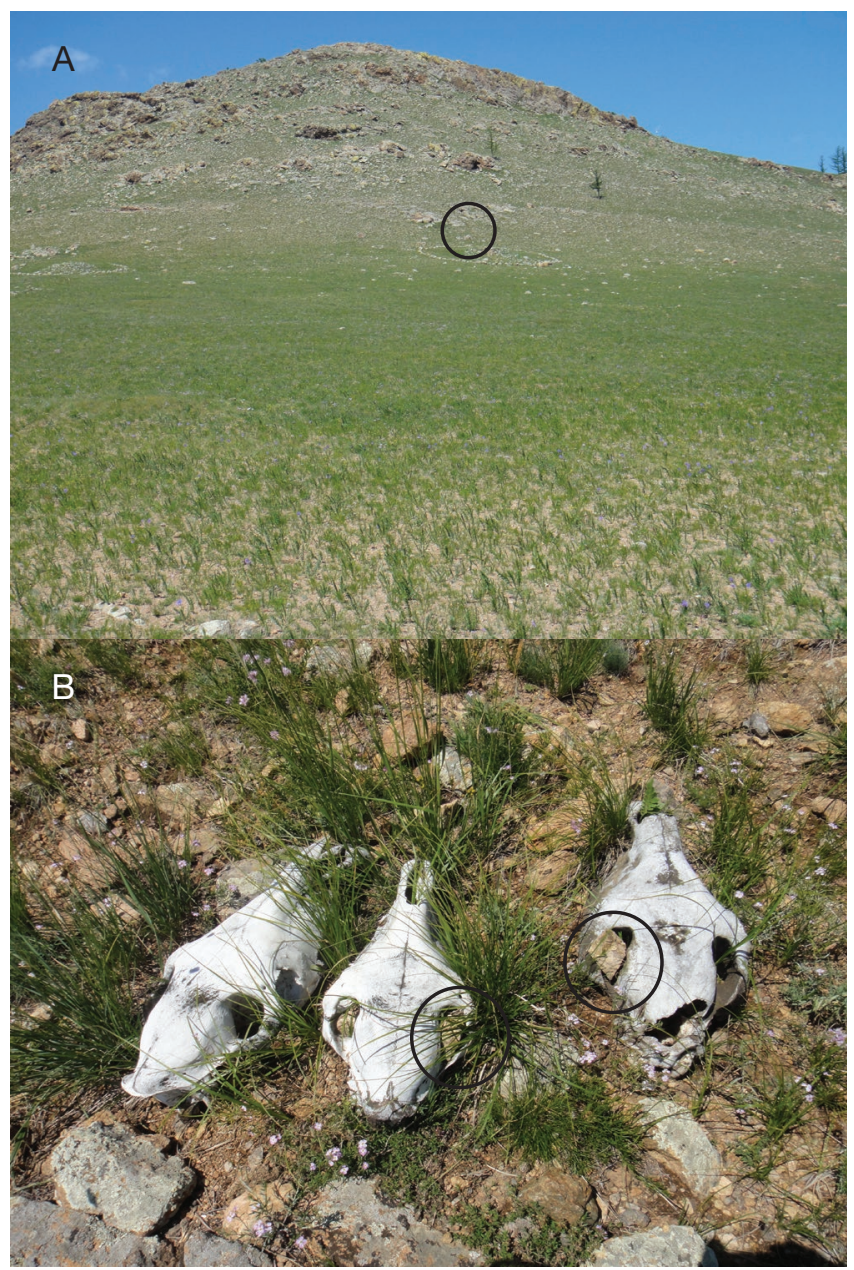

FIG. 6. - Stones placed in the skull's cavities: A, skulls located west of the archaeological structure; B, stones inserted between the temporal cavity and the zygomatic arch.

if they felt "lazy" (zalkhuu). Moreover, the placing of a skull on a sheepfold roof is not restricted to horses, as it was also noted for cattle and camels.
The horse, therefore, holds the status of respected animal, which confers him a different slaughtering and post-mortem treatment to the other raised species. However, the amalgamation of our observations and the interviews sheds light on a discrepancy between the treatment described in the herders' discourses (i.e. no ante-mortem stunning by hitting the forehead; skull placed on an ovoo) and the actual treatment (i.e. stunning, skull placed in a tree or on the roof of a sheepfold, due to "laziness").

\section{FROM SPECIES TO INDIVIDUALS AND FROM TREE TO OVOO: DIFFERENTIATION PROCESSES IN A HORSES' DEATH}

Mongolian herders eat horse meat, but not the meat of any horse. As with other species, the meat of a horse which died from old age, sickness, or natural disaster, is not considered edible. Most of the herders from Bayantsagaan stated that they do not slaughter stallions, which should be left to die in peace. One herder mentioned the exception of a very old stallion who had lost its teeth and could not feed itself anymore. Some herders also spared the slaughter of beloved riding, race, and consecrated horses. These horses are thus, together with stallions, considered and treated as special individuals.

What we call a "horse" may be designated in Mongolian by two distinct terms: aduu - describes the generic horse, as a member of the herd, which provides products, and mor' - a horse that is mounted or saddled and seen more as an individual companion. Nevertheless, the categories aduu and mor' are not exclusive, and are more like a functional duplication. Indeed, a vast proportion of the herd horses, mostly geldings but also mares, are occasionally ridden, and the horses shift between these two categories on a regular basis (see Marchina 2016: 103, 104). When needed, riding and race horses are momentarily taken out of the herd, which graze freely, and are kept for several consecutive days at the encampment. In this way, herders develop more intimate relations with these animals as they are in daily contact with them. In contrast, the consecrated horses (setertei mor) have little contact with humans and are left to roam free with the herd. They are considered as the mount of the spirits and should not be ridden, touched, or sometimes even slaughtered, in order to protect the herd and the encampment (see Rashidonduk 1970: 210, 211; Heissig 1979: 394).

Aside from particular individuals, both male and female horses may be slaughtered. All herders stated that they did not eat the meat of a foal (unaga, a horse in its first year), but that a horse can be slaughtered at any age from one year old. Some expressed their preference for young horses (three or four years), because their meat is generally fatter and more tender. Others, on the contrary, prefer older horses, whose usefulness is limited. Others chose a horse according to its size, in relation to the number of the people they had to feed come winter. After the horse has been slaughtered and eaten its skull is placed in a high location. When a horse is found dead, its head is simply detached from its body, which is disregarded, and deposited as it is, either with or without the mandibles. 
The possibility of slaughtering a horse is therefore strongly linked to its status, which also has an impact on the way its skull is treated after death. One example of such a distinction, can be made between the different items deposited with ordinary and beloved horses. Several skulls left on ovoos were wrapped in a khadag (Fig. 5): a ritual scarf constituting an honorific sign which often accompanies gifts to humans and offerings to spirits. According to the herders we interviewed, besides the khadag, other items can be placed with the skull, such as other bones from the horse (e.g., its legs, if it was a race horse; sometimes the hooves). One herder reported that he sometimes places stones in the cavities of the skull (see also Tatár 1984: 323), to signify that he and the dead horse shared a history and a friendship together (Fig. 6). This same herder talked about the skull repositories less in terms of the horse's status, and more in terms of the relationships he had had with particular individuals. According to him, placing a skull on an ovoo is a way to acknowledge and thank an animal he has known from its birth and that he has ridden. In light of this data, the practice of placing skulls in particular places appears to be at least as much an offering to the spirits - or to nature (see Tatár 1984: 323, who interprets horse skull repositories as an obligation to give back to nature the animal that was killed) - as gratefulness expressed to the horse.

Over the course of the interviews, several herders introduced differentiation in the places where a skull is placed, according to the relationship they had had with the horse: between ordinary horses - where the skull is left on the top of a hill, in a tree, or on a rock; and beloved horses (i.e. a good riding horse, a racehorse, a good mare, or a stallion) - where the skull is placed on the more honoured ovoo. One herder gave us his account of a six hour journey he undertook to the peak of a very high mount, relatively far away from his encampment, where he placed the skull of an old stallion on a 15 metre high rock. In fact, it was only in these very remote, high locations, close to big ovoos, that we found skulls wrapped in a khadag, far away from tracks and roads.

The differentiation in the locations of horse skull repositories led us to examine the different kinds of ovoos which exist in various configurations. We found that although horse skulls were located on each kind of ovoo, not all categories of horses were represented: the skulls of ordinary horses were never found on the highest ovoos.

In the surroundings of Bayantsagaan, the smallest ovoos were simple rock piles (tens of $\mathrm{cm}$ high) on the hills, which seemed to have been erected by and for the people of the valley, in non-official contexts. Passersby and local families leave stones and offerings on these ovoos, once or several times a year. Some bigger versions of these ovoos, which included a metal bar or a wooden stick driven into the pile, were found on top of higher hills (Fig. 7). The herders explained that the metal bar played the role of a relay antenna, as the local people, in these enclosed valleys, enjoyed a better radio reception when they orientated their antennas in the direction of the repositories. ${ }^{3} \mathrm{We}$ also observed a large number of metal items, including the wreck

3. We are, however, not able to explain how this could work.
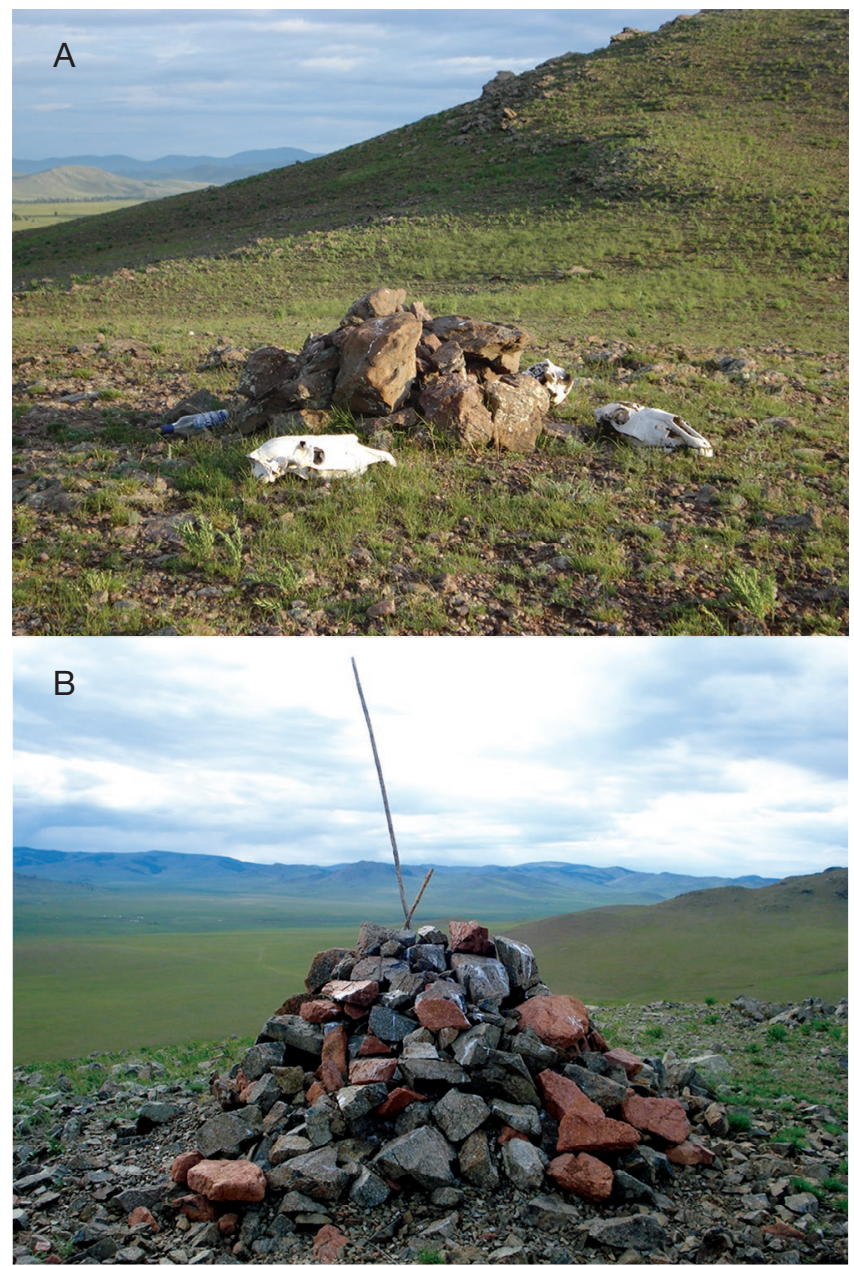

FIG. 7. - A, Small ovoo with horse skulls at the top of a hill; B, bigger ovoo including wooden sticks.

of a car, on some burial mounds of archaeological funerary structures of the khirigsuur type (Fig. 8). According to the herders, they also play the role of relay antenna. However, the leaving of metallic objects is not solely restricted to this usage, as testified to by the numerous metallic items found on the mounds of another khirigsuur, along with the bones of various animals, including wild fauna (Fig. 9). When the herders were questioned on this subject, they stated that they ignored the existence of those repositories. Some mounds, therefore, interestingly appear simultaneously as places for honorific offerings and for discarded items. However, the latter seem to fall into a very particular kind of refuse, which inevitably makes one think of the Mongolian capital's cemeteries where various items are disposed of, including unusable metallic objects and other "non-perishable waste very typical of the industrial urbanity" (Delaplace 2008: 122). On the steppe, however, non-biodegradable products are generally gathered in a pile outside the encampment. Conversely, the carcasses of animals - after mass deaths from epizootic disease or natural disasters such as a zud (see Lacaze \& Marchina 2013) - are collected and dumped (and sometimes burned) far away in mass graves. It is, therefore, interesting to note that some 


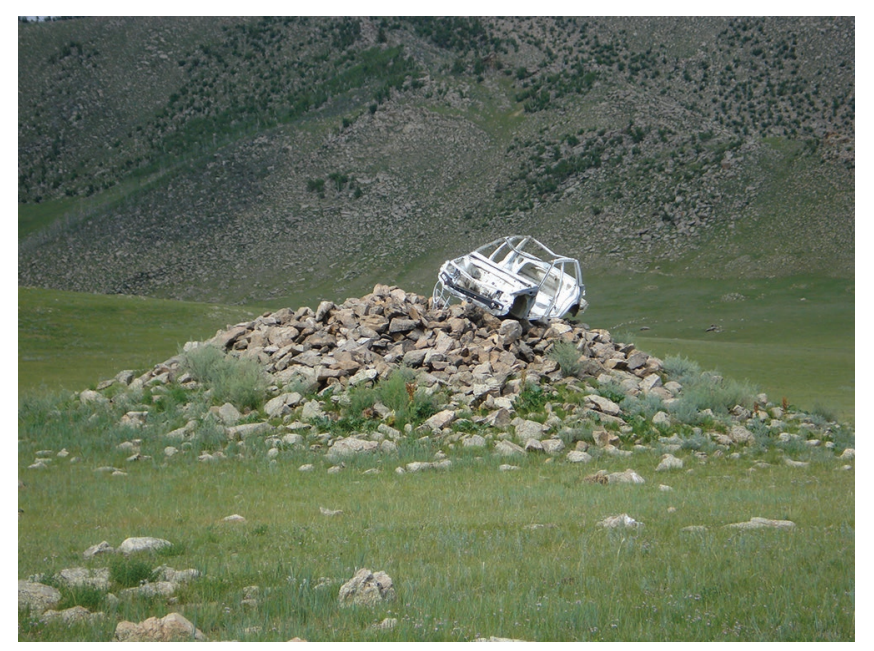

FIG. 8. - The wreck of a car placed with other metal items on the mound of a khirigsuur.

khirigsuur mounds have various contemporary usages: backing for a relay antenna, a dump for specific unwanted items, or a substitute for an ovoo - some skulls were found nearby (Fig. 6).

The second kind of ovoos, are more complex and imposing structures, a few metres taller than their smaller, simpler neighbours. These ovoos consist of a conical structure made up of wooden poles, surrounded by small peripheral stone ovoos. These very highly situated ovoos, though much less numerous, have an official character and host formal rituals such as the annual Buddhist ovoo takhilga ceremony during which herders from the valley gather for prayers and offerings (see also Pedersen 2011: 143-145 and Vreeland 1954: 262-264). Unlike the other ovoos, women are not allowed to attend them or the rituals they host. Nevertheless, they join the men for "three manly games" (eriin gurvan naadam) - horse races, wrestling, and archery - which follow the ceremony, at the foot of the hill, and which are supposed to entertain the spirits (see Lacaze 2000).

The simplest configurations of ovoos are the most common. Of the 220 ovoos surveyed in the surroundings of Bayantsagaan only one revealed the most complex form, mentioned previously. This imposing structure is located on one of the areas most prominent hilltops, at an elevation of $1776 \mathrm{~m}$ (with an altitude of $1500 \mathrm{~m}$ in lowland areas) (Fig. 10). The constitution of this ovoo matches the description given by the Russian ethnographer Ksenia Gerasimova: an altar made of stone, an approximately four metre high conical construction made up of wooden poles which compose the central ovoo, and stone piles which stretch out from the central structure towards the four cardinal points. This configuration is supposed to represent the Buddhist conception of the world (Gerasimova 1981: 164). In front of the central ovoo are tables around which a multitude of offerings (e.g., banknotes, khadag, vessels) are scattered. The ceremonial space is located on the south side of the ovoo and is open towards the mountain's edge; it is surmounted by 29 small stone mounds (extending out $54 \mathrm{~m}$ ). The north side of the peak is also composed of an edge containing 12 mounds

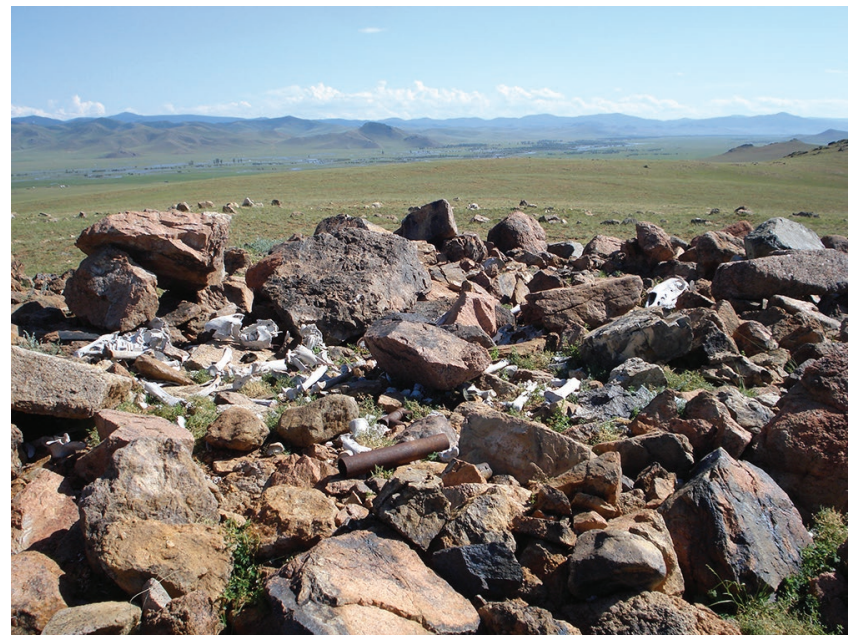

FIG. 9. - Repository of metallic items and various animal bones on the central mound of a khirigsuur.

(lined up over $21 \mathrm{~m}$ ); this north-south axis intersects at right angles a second east-west axis, consisting on the west side of 14 mounds $(27 \mathrm{~m})$ and on the east side in two rows of 14 and 7 mounds (stretching out over 24 and $12 \mathrm{~m}$ ). The whole structure, therefore, forms a cross marking the four cardinal points, at the centre of which is placed the main ovoo. A few hundred metres below this, is a differently constructed ovoo: a cylindrical structure of stones, with a central pole adorned with prayer flags, and a fireplace at its foot where offerings might have been burnt (Fig. 11). The herders of Bayantsagaan mentioned that exceptionally ceremonies may be organised on this imposing ovoo during cases of drought or the poor condition of livestock. According to one herder, the bigger ovoo is called "foal" (unaga), while the smaller one, to which it is associated, bears the name "mother" (eezh) (or "mare" (gü̈̈), according to another herder). He explained that these names were given to the two ovoos during construction, in an effort to ensure the prosperity of the horses at a time when they were ailing. Kircher (1667: 70) has already mentioned the protectional function of the ovoos for humans and horses, in particular. In June, the larger of the two ovoos usually hosts the sub-district's $(b a g)$ herders at the official annual Buddhist ceremony. During this ritual, the ovoos structure is reinforced by the herders who insert an additional wooden pole, adjacent to the other poles which compose the conical structure (see Fig. 10), prayers are read and meat offerings (generally mutton) are made.

This highly placed ovoos revealed five horse skulls; however, none of these were directly associated with the main structure (Fig. 10). One of the skulls (an old male) was located nearby, on the east branch of the monument next to the third secondary mound. The other four items were placed on the longest branch, the south: skull " $B$ " (an old male) was located between mounds four and five; skull "C" (10 to 11-year-old male), was found between the fifth and the sixth mound; skull "D" (15 to 18-year-old male) after the sixth mound, but it seems to have rolled from its initial position 

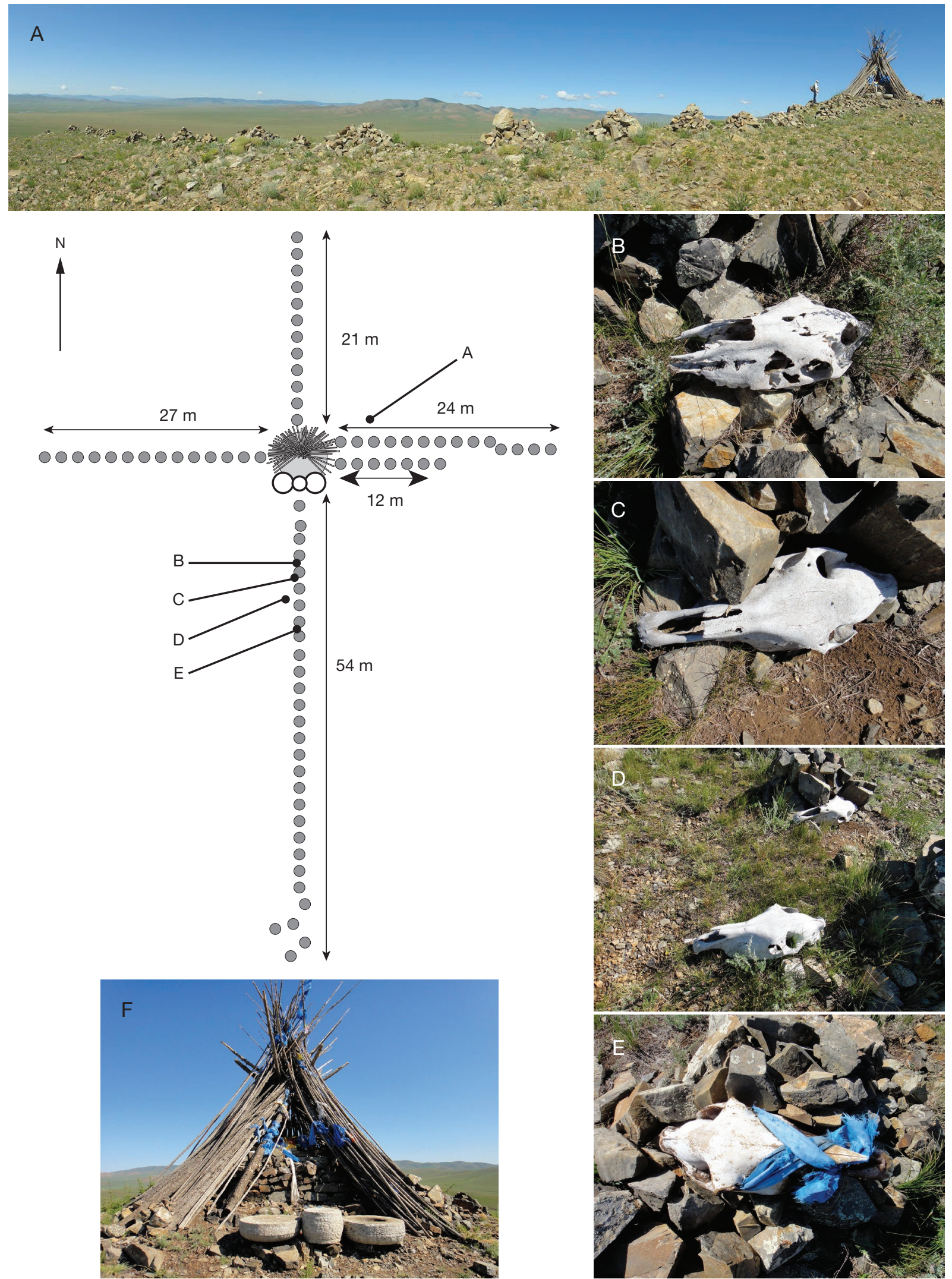

FIG. 10. - Structure and repositories associated with the great "foal" ovoo: A, central ovoo and small stone cairns stretching out towards the south; B, old male horse skull; C, 10 to 11-year-old male horse skull; D, 15 to 18-year-old male horse skull; E, old male horse skull wrapped in a khadag; F, central ovoo with its altar. 


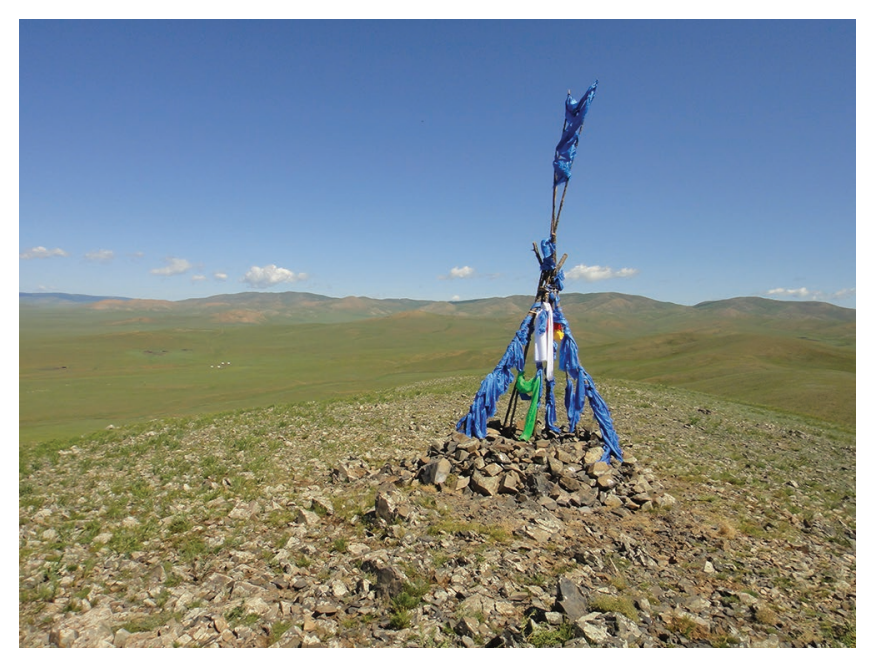

FIG. 11. - "Mother" ovoo, associated with but located below the "foal" ovoo.

towards the west, possibly as a result of wildlife or livestock passage; and skull "E" (an old male) was found between the eighth and the ninth mound - seemingly, it was placed there shortly before our visit as it was still wrapped in a khadag and had not fully decomposed. We can see, therefore, that the number of skulls placed on the biggest structures is limited. In general, the deposits are then left on the peripheral cairns rather than at the foot of the main ovoo, as in the case of the "foal" ovoo. During an interview, one herder reported that the repository location should not be too highly elevated, because the horse herds might become unstable. According to him, the location of a skull had a direct impact on the behaviour of the other horses. Possibly because of this, the leaving of skulls on smaller ovoos lower down the hillside is much more common.

\section{FROM AN OVOO TO SOMEONE'S OVOO: UNFOLDING HUMAN-HORSE RELATIONS IN THE LANDSCAPE}

Historians and anthropologists have given ovoos the role of border delimitations (Atwood 2004: 414) or of assembly points for local authorities to discuss political and administrative issues during the Sino-Manchu period (1644-1911) (Jagchid \& Hyer 1979: 121), roles that have completely disappeared today. However, among the Mongols, ovoos remain a revered meeting place for the annual, largely Buddhist, ceremony (ovoo takhilga) which takes place in the summer. Through these significant, official, and collective ceremonies, herders expect protection and prosperity from the invisible entities with which they share the land. Honour is awarded daily to those spirits through many actions. First, the herders must respect the master spirits of the land (gazryn ezen) by preserving environmental resources (e.g., not polluting the sources, only cutting wood in reasonable and necessary quantities) and by avoiding behaving as masters of the land themselves (Delaplace 2013: 105, 106).
Human activity should not disturb the spirits through the digging or needless marking of the ground (Tatár 1984: $321,322)$, as this can provoke their wrath. Nonetheless, the herders think they can tame the spirits' unpredictable forces and encourage positive effects through ritualised actions (Humphrey 1995: 137): daily offerings are made by the women in the form of libations (tsatsal), performed outside with the first morning tea, and meat and sweets are placed on the domestic altar in the yurt. In addition to these daily and regular actions, exceptional rituals are also dedicated to the spirits in the form of animal consecrations and the cult of the ovoos. During all these actions, it is the animals, whether dead (i.e. meat offerings, skulls) or alive (consecrated animals), or their products (milk) that act as intermediaries between the humans and the invisible entities who inhabit this shared territory (nutag).

The size of this nutag ("land" or "country") has a variable scale depending on the interlocutor: from the district (sum) to the state, including the province (aimag). In a narrow view, the nutag refers to the place where one lives within the district (sum); this encapsulates their entire nomadic territory including the winter and/or spring encampments, which are the only "place" of residence officially declared to the administration by the herders. The nutag often implicitly refers to the "native land" (törsön nutag): the place where one is born. Traditionally, it is in their nutag that a person's placenta is buried (Lacaze 2012: 74-77). It is recommended that people do not stay away from their nutag for a long period of time, otherwise they will not be fully protected by the local spirits, and they should also be buried there (see Delaplace 2008: 143-148; Charlier 2013; 2015: 150-152). Therefore, the term nutag refers to more than just a place; it also encompasses the network of relations people maintain with other people - whether kin or neighbours - and the invisible entities. Consequently, the ovoos stand as a materialization of all these relationships within a shared environment, and together with the homage paid to the spirits through offerings and prayers, the collective ceremonies held here are the reaffirmation of a community and territorial belonging (see Vreeland 1954: 262-264; Pedersen 2011: 143-145).

However, the smallest ovoos, unofficially erected by the herders themselves, are in fact the main type of ovoo to host horse skulls. Some herders said they placed a skull on the same mountain every year, while others stated that they changed the location annually, or that they used up to five different hills. Aside from the skulls of exceptional horses, placed, as previously mentioned, in highly elevated locations, horse skulls are normally just left in high places located close to the herders' encampments. According to certain herders, some ovoos are even unofficially allocated to particular families, with some of them stating that they place skulls on their deceased parent's ovoo in order to maintain a link with them.

The ovoos that did host skulls rarely had more than three, apart from one where around forty skulls had been placed. Intrigued by this exceptional assemblage (Fig. 12), we inter- 


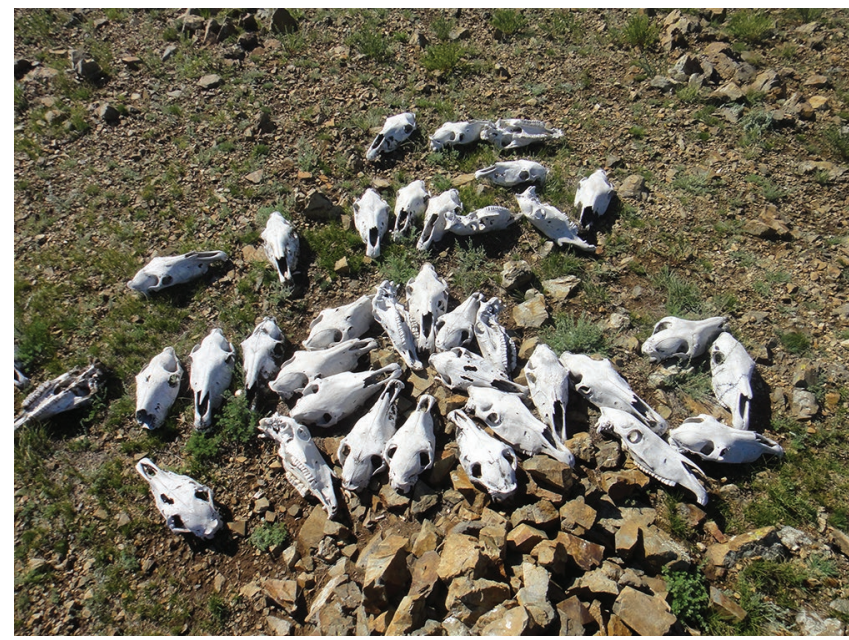

FIG. 12. - Skulls placed by Sambuu on his ovoo.

viewed the herders living nearby. Several of them said they had no idea about the existence of those repositories, until one herder suggested asking his elderly neighbour, Sambuu, who confessed that he had made the deposits, and that the large amount of skulls was simply due to this being his nutag ("minii nutag": "my nutag"). Sambuu went on to say that he and his family slaughter and eat one to two horses per year, and that it was during the time of Tsedenbal (head of the Mongolian State from 1974 to 1984) that he began to leave skulls there. He only ceased about ten years ago because he was no longer able to do it himself. Since then, his children had taken care of placing the skulls, but in other locations. He said that although his children shared the same nutag as him, he was more linked to this ovoo. Sambuu's ovoo displays no less than 42 skulls: 37 placed right next to the stone cairn, and five others, found further down the slope, which had probably rolled away. Analysing the skulls of these horses (Fig. 13) allowed us to determine that most of them were slaughtered at less than four years old or, on the contrary, in old age. In interviews, the herders stated that they considered any horse over 15-20 years as old. For Sambuu and other herders, the placing of skulls on ovoos is thus a matter of expressing an attachment to a territory and to the entities which inhabit(ed) it.

Tseden-Ish, who usually places his horse skulls in different places, stated that knowing where a skull is located is his way to remember a specific horse, and he took us to the hill closest to his winter encampment where he had placed the skull of an old mare he used to ride. Several herders said that they placed the skulls on hills near the pastures where their horses used to graze. In fact, the nutag is considered as much the animals', and most notably the horses', as it is the humans'. It is common to hear the horses' nutag depicted as a place they often try to return to after they have been sold. Stories about horses recently being bought and running back to their former pastures are frequent. Tseden-Ish respects the horses' attachment to their nutag by orienting the skull towards the encampment (i.e. the nutag in its nar-

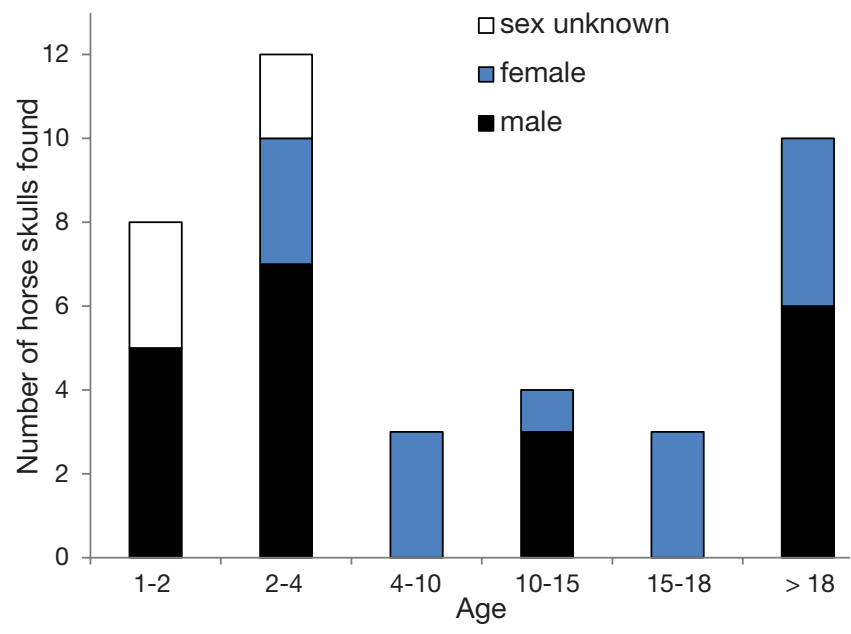

FIG. 13. - Number of horse skulls per age group (in years) and sex, on Sambuu's ovoo. While sex distribution is even, we can see that most of the slaughtered animals are either young (less than four years old) or old. The method used to determine the animals' age is based on the analysis of dental eruption and the degree of wear (Cornevin \& Lesbre 1894; Lepetz 2013).

rowest sense). Nevertheless, according to the correlation between the repositories we observed and the information from the herders, we found significant variability in the skulls' orientation. Aside from the case of some herders who stated that the orientation has absolutely no importance, we identified two kinds of orientations: relative - depending on the horse's nutag -, and absolute - in relation to the four cardinal points. The most common absolute orientations mentioned by the herders are north, south, east ("towards the sun") and south-east. Some herders choose to orient the skull towards the south or south-east so that it always faces the sunlight. While the north is the honorific direction among the Mongols - the domestic altar being always located in the northern part of the yurt - the door of the yurt generally faces the south (Lacaze 2006), and more precisely the south-east along the Tamir river in Bayantsagaan. Variability in orientation was also found at Sambuu's ovoo, and we identified two patterns in the layout of the items, with some exceptions (Fig. 12). A series of skulls had been disposed radially around the base of the stone cairn, without systematic regularity regarding the convergence of the front and rear parts of the skulls. Another series includes skulls broadly placed northwards, sometimes adjacent.

Therefore, much like human remains, the horse's skull stays in its nutag, or is oriented toward it. In fact, Grégory Delaplace (2008: 146) notes that if a man cannot be buried in his nutag, his body may be oriented towards it. This is somewhat reminiscent of the destiny of the hero and his horse in Turko-Mongolian epic poetry who share the same place of birth (Veit 1981: 111) and death (Potapov 1977: 86). Leaving skulls in high places is therefore a way of expressing a relationship to one's nutag and the entities with which it is shared (i.e. master spirits, ancestors); but by doing so, herders also materialize a relation of identity with individual horses within the same shared territory. 
In practice, this custom is one way to discretely reaffirm territorial anchorage via relations that are entwined with the horses whose skulls are placed throughout the landscape. In this region of Mongolia, encampments of colder seasons (i.e. autumn, winter, spring) are located in the valley bottoms or on hillsides, so as to protect humans and herds from freezing winds; while summer encampments are situated on the plains, in the airstream, and along the rivers (Marchina 2013). Ovoos, most often found on hills, and the skull repositories associated to them are therefore closer to the encampments of cold seasons, which are also the place where the horses are slaughtered, between October and December (Fig. 2). As occupants of their nutag, which they cannot openly appropriate if they do not want to upset the master spirits, and in the absence of private land ownership on the Mongolian steppe, the herders materialize their occupancy by the building of massive winter encampments which cannot be moved (see Kazato 2005; Endicott 2012: 110-119), and by erecting ovoos which they adorn with offerings. Horse skull repositories strengthen these links and represent the combined attachment from men to land, from horses to land and from men to horses.

\section{CONCLUSION}

In Bayantsagaan, the custom of horse skull repositories and the discourses provided by the herders highlight the horse's ability, through its skull, to connect the herder, the location (e.g., a mountain, an ovoo, a nutag), and the invisible entities which inhabit the nutag. Skulls and ovoos litter numerous mountains and hills across the herders' nutag. They are marks of gratitude and honour, as much to their horses as to the invisible entities, whilst also constituting a form of territory appropriation, which remains discreet by avoiding expanding onto the highest ovoos. As Caroline Humphrey has already noted, ovoos are a way of saying "We are here" (Humphrey 1995: 146). This statement is reinforced by the horse skulls which individualize the ovoos, and implicitly mark them as belonging to one or several herders. In turn, the herders closely limit this form of appropriation within what is allowable by the master spirits of the land. Modalities of skull repositories are defined by factors such as the status of the animal, the place of residence of its herder, and the relations he has with his nutag. Considering the landscape variations and regional differences in preferential deposit practices in Mongolia, horse skull repositories should be further explored; not only to shed light on ancient ritual practices, but also to better understand the triadic relation between humans, animals and territory.

\section{Acknowledgements}

The authors wish to express their gratitude to William Taylor and the other anonymous reviewer for their helpful comments and suggestions.

\section{REFERENCES}

Allard F. \& ERdenebaAtar D. 2005. - Khirigsuurs, ritual and mobility in the Bronze Age of Mongolia. Antiquity 79 (305): 547-563. https://doi.org/10.1017/S0003598X00114498

Allard F., Erdenebaatar D., Olsen S., Caralla A. \& Maggiore E. 2007. - Ritual and horses in Bronze Age and present-day Mongolia: some preliminary observations from Khanuy Valley, in Popova L., Hartley C. \& SMith A. (eds), Social Orders and Social Landscapes. Newcastle upon Tyne, Cambridge Scholars Press: 151-167.

ATwood C. P. 2004. - Encyclopedia of Mongolia and the Mongol Empire. Facts on File, New York, 678 p.

Baroni I., Gantulga J.-O., Magail J. \& Yeruul-Erdene C. 2016. - Three thousand years of nomadism on the Tsatsyn Ereg site in the heart of Mongolia, in BiageTti S. \& Lugli F. (eds), The Intangible Elements of Culture in Ethnoarchaeological Research. Springer International Publishing, Cham: 151-159. https://doi.org/10.1007/978-3-319-23153-2_10

BirTALAN Á. 2003. - Ritualistic use of livestock bones in the Mongolian belief system and customs, in SÁRKÖZI A. \& RÁKOS A. (eds), Proceedings of the $45^{\text {th }}$ Permanent International Altaistic Conference (PIAC), Budapest, Hungary, June 23-28, 2002. Eötvös Loránd University, Budapest: 34-62.

Broderick L. G., Houle J.-L., Seitsonen O. \& Bayarsaikhan J. 2014. - The mystery of the missing caprines: stone circles at the Great Khirigsuur in the Khanuy valley. Studia Archaeologica Instituti Archaeologici Academiae Scientiarum Mongolicae 34 (13): 164-174.

Broderick L. G., Seitsonen O., Bayarsaikhan J. \& Houle J.-L. 2016. - Lambs to the slaughter: a zooarchaeological investigation of stone circles in Mongolia. International Journal of Osteoarchaeology 26: 537-543. https://doi.org/10.1002/oa.2425

Charlier B. 2013. — L'attachement au "pays natal" chez les Mongols, in Stépanoff C., Ferret C., Lacaze G. \& Thorez J. (eds), Nomadismes d'Asie centrale et septentrionale. Armand Colin, Paris: $103-105$.

CHARLIER B. 2015. - Faces of the Wolf. Managing the Human, NonHuman Boundary in Mongolia. Brill, Leiden, 188 p.

Cornevin C. \& Lesbre F.-X. 1894. - Traité de l'âge des animaux domestiques d'après les dents et les productions épidermiques. Paris, Baillière, $462 \mathrm{p}$.

DelaPlaCE G. 2008. - L'invention des morts: sépultures, fantômes et photographie en Mongolie contemporaine. Centre d'Études Mongoles et Sibériennes; École Pratique des Hautes Études, Paris, 374 p.

Delaplace G. 2013. - Habiter le "pays" sans vivre nulle part, in Stépanoff C., Ferret C., Lacaze G. \& Thorez J. (eds), Nomadismes d'Asie centrale et septentrionale. Armand Colin, Paris: $105-107$.

DJAKONOVA V. P. 1977. — L'obo, monument culte de la nature chez les peuples du Saïan-Altaï. L'Ethnographie 118 (74-75): 93-99.

ENDICOTT E. 2012. - A History of Land Use in Mongolia: The Thirteenth Century to the Present. Palgrave Macmillan, New York, 242 p.

Ferret C. 2004. - De l'attache des chevaux à la fécondation des femmes en passant par la cuisine. Quelques pistes pour l'exploration des notions altaïques de chaud et de froid. Etudes rurales 171-172: 243-270.

FERRET C. 2009. - Une civilisation du cheval. Les usages de l'équidé de la steppe à la taïga. Belin, Paris, 352 p.

FERRET C. 2014. - Des chevaux qui accompagnent les morts en Asie centrale, in BEDE I. \& DENTE M. (eds), Rencontre autour de l'animal en contexte funéraire. Actes de la 4e Rencontre du GAAF. Groupe d'anthropologie et d'archéologie funéraire, Saint-Germain-en-Laye: 239-250.

FitzHugh W. 2009. - The Mongolian deer stone-khirigsuur complex: dating and organization of a late Bronze Age menagerie, in Bemmann J., Parzinger H., Pohl E. \& TseveEndorj D. (eds), Current Archaeological Research in Mongolia: Papers from the $1^{\text {st }}$ 
International Conference on Archaeological Research in Mongolia Held in Ulaanbaatar, August 19th-23rd, 2007. University of Bonn, Bonn: 183-199.

FIJN N. 2011. - Living with Herds. Human-Animal Coexistence in Mongolia. Cambridge University Press, Cambridge, 274 p.

GERASIMOVA K. M. 1981. - De la signification du nombre 13 dans le culte des obo. Études Mongoles 12: 163-175.

HeISSIG W. 1979. - A note on the custom of Seterlekü. Harvard Ukrainian Studies 3-4 (1): 394-398.

Humphrey C. 1995. - Chiefly and shamanist landscapes in Mongolia, in Hirsh E. \& O'Hanlon M. (eds), The Anthropology of Landscape: Perspectives on Place and Space. Clarendon Press, Oxford: 135-162.

JagChid S. \& Hyer P. 1979. - Mongolian Culture and Society. Westview Press, Boulder, 461 p.

KagAROV E. G. 1927. — Mongol'skie "obo" i ikh etnograficheskie paralleli. Sbornik muzeya antropologii i etnografii 6: 115-124.

KaZATO M. 2005. - What is o'voljoo for the Mongolian Herders? The Right to Land in Pastoral Regions in Postsocialist Mongolia, in Hiramatsu K. (ed), Coexistence with Nature in a 'Glocalizing' World. Field Science Perspectives. Kyoto University, Kyoto: 239-246.

KIRCHER A. 1667. - China monumentis, qua sacris qua profanis, nec non variis naturae \& artis spectaculis, aliarumque rerum memorabilium argumentis. Amsterdam, $248 \mathrm{p}$.

LACAZE G. 2000. - Rite de renouveau ou fête nationale: la lutte et le tir à l'arc dans les jeux virils mongols. Études Mongoles et Sibériennes, Centrasiatiques et Tibétaines 30-31: 73-123.

LACAZE G. 2006. - L'orientation dans les techniques du corps chez les Mongols. Études Mongoles et Sibériennes, Centrasiatiques et Tibétaines 36-37: 163-205. https://doi.org/10.4000/emscat.810

LACAZE G. 2012. - Le corps mongol. Techniques et conceptions nomades $d u$ corps. L'Harmattan, Paris, $354 \mathrm{p}$.

LACAZE G. \& MARCHINA C. 2013. - Les zud, grandes catastrophes du pastoralisme des steppes, in STÉPAnoff C., Ferret C., LaCAZE G. \& ThOrez J. (eds), Nomadismes d'Asie centrale et septentrionale. Armand Colin, Paris: 48, 49.

LEPETZ S. 2013. - Horse sacrifice in a Pazyryk culture kurgan: the princely tomb of Berel' (Kazakhstan). Selection criteria and slaughter procedure, in ARBOGAST R.-M. \& LEPETZ S. (eds), Animals in funerary space. Anthropozoologica 48 (2): 309-322. https://doi.org/10.5252/az2013n2a9

MagaIL J. 2008. - Tsatsiin Ereg, site majeur du début du Ier millénaire en Mongolie. Bulletin du Musée d'Anthropologie préhistorique de Monaco 48: 107-120.

MagAiL J. 2015. — Les stèles ornées de Mongolie, dites "pierres à cerfs", de la fin de l'âge du Bronze, in Rodriguez G. (ed), Actes du 3ème colloque international sur la statuaire mégalithiques: Pierres levées du Néolithique à l'âge du fer. DRAC Languedoc-Roussillon, GASP, Saint-Pons-de-Thomières: 89-101.

MarCHINA C. 2013. — Le pastoralisme de Mongolie, in STÉPANOFF C., Ferret C., Lacaze G. \& Thorez J. (eds), Nomadismes d'Asie centrale et septentrionale. Armand Colin, Paris: 43-47.
MARCHINA C. 2015. - Faire communauté. Etude anthropologique des relations entre les éleveurs et leurs animaux chez les peuples mongols (d'après l'exemple des Halh de Mongolie et des Bouriates d'Aga, Russie). Thèse de doctorat, Institut national des Langues et Civilisations orientales, Paris, 365 p.

MARCHINA C. 2016. - 'Follow the horse': the complexities of collaboration between the lasso-pole horse (uurgach mor') and his rider among Mongolian horse herders, in DAVIS D. \& MAURSTAD A. (eds), The Meaning of Horses: Biosocial Encounters. Routledge, London: 102-114.

Pedersen M. A. 2011. - Not quite Shamans. Spirit Worlds and Political Lives in Northern Mongolia. Cornell University Press, London, Ithaca, $250 \mathrm{p}$.

Popov A. A. 1949. - Materlialy po istorii religii yakutov Vilyuiskogo okruga [Materials on the religious history of the Yakuts from the Vilyuisk district]. Sbornik muzeya antropologii i etnografii 11: 254-323.

POTAPOV L. P. 1977. — Signification rituelle du pelage des chevaux chez les populations saiano-altaïennes. L'Ethnographie 74-75: 81-92.

RASHIDONDUK S. 1970. — On seter, in CH'EN C. (ed), Proceedings of the Third East Asian Altaistic Conference, August 17-24, 1969, Taipei, China. National University of Taiwan, Taipei: 210-212.

Seitsonen O., Houle J.-L. \& Broderick L. G. 2014. — GIS approaches to past mobility and accessibility: an example from the Bronze Age Khanyu valley, Mongolia, in Leary J. (ed), Past Mobilities: Archaeological Approaches to Movement and Mobility. Ashgate Publishing, Farnham: 79-112.

STÉPANOFF C. 2013. - Paysages sacrés et "lieux habités" chez les Tožu, in Stépanoff C., Ferret C., Lacaze G. \& Thorez J. (eds), Nomadismes d'Asie centrale et septentrionale. Armand Colin, Paris: 107, 108.

Stépanoff C., Ferret C., LaCAZE G. \& Thorez J. (eds) 2013. Nomadismes d'Asie centrale et septentrionale. Armand Colin, Paris, $287 \mathrm{p}$

TATÁR M. 1971. - Zur Fragen des Obo-Kultes bei den Mongolen. Acta Orientalia Academiae Scientarum Hungaricae 24 (3): 301 330. http://www.jstor.org/stable/23657123

TATÁR M. 1976. - Two Mongol texts concerning the cult of the mountains. Acta Orientalia Academiae Scientarum Hungaricae 30 (1): $1-58$

TATÁR M. 1984. - Nature protecting taboos of the Mongols. Tibetan and Buddhist Studies 29 (2): 321-325.

TAYLOR W. 2017. - Horse demography and use in Bronze Age Mongolia. Quaternary International 436 (A): 270-282. https:// doi.org/10.1016/j.quaint.2015.09.085

VEIT V. 1981. - Einige Überlegungen zu natürlichen und übernatürlichen Aspekten bezüglich des Pferdes im Mongolischen Epos, in HeIssig W. (ed), Fragen der mongolischen Heldendichtung. Otto Harrassowitz, Wiesbaden: 109-117.

VReEland H. H. 1954. - Mongol Community and Kinship Structure. Yale University, New Haven, 359 p.

ZhambaldorZH S. 1996. - Morin Erdene [Treasure Horse]. Ulaanbaatar, $254 \mathrm{p}$. 
